\title{
DEATH AND VIOLENCE IN CONTEMPORARY THEATRE, DRAMA, AND NOVEL (OLIVER FRLJIĆ, ANJA HILLING, SIMONA SEMENIČ, AND G. W. SEBALD)
}

Summary. For the purpose of my examination of how literature and art take part in the circulation of significations and representations in the construction of social reality, I concentrate on a specific feature that links and unites the work of four contemporary European authors-the inflation of death and violence, or the "overflow of corpses" in their novels, plays, and performances. My first example will be Bosnian-Croatian theatre director Oliver Frljić, his disturbing, shocking performances in which he uses his own personal, wartime, and political traumas to ask universal questions about the boundaries of artistic and social freedom, individual and collective responsibility, tolerance and stereotypes. As the second and third example I will take plays by two (no longer) dramatic writers, Anja Hilling and Simona Semenič-two outstanding representatives of German and Slovene (no longer) dramatic theatre and drama, exploring in their texts a tension between repetition and representation in which the first mechanism undermines and challenges the second and produces a specific poetic or aesthetic device-an effect of ostranenie or defamiliarisation (Shklovsky). The third example will consist of the novels by Winfried Georg Sebald, in which the German author uses the device of his wanderings between signs, punctuated by black and white photographs, producing a specific emblematic of a mutation of space and time, in which history and geography cross-fertilise, tracing out paths and weaving networks. Besides examining the contestation of subject positions, I concentrate on the dialectics of art and society, where fluid, uncontainable subjects are constantly pushing the contours. Revising the critical consensus that contemporary art primarily engages with the real, the essay describes how theatre and fiction today navigate the complexities of the discourse as well as social realities; how the discussed artists all share the belief that creative expression must also be destruction. Art has to go beyond what we are and what we can identify through understanding. Thus, art negotiates, inflects discursive circulation of stories, idioms, controversies, testimonies, and pieces of (mis)information in the face of global uncertainties.

Keywords: Winfried Georg Sebald, Oliver Frljić, Simona Semenič, Anja Hilling, contemporary theatre, difference and repetition, politics of theatre and fiction, European theatre, collaborative theatre, altermodernism.

\section{TENSION BETWEEN REPETITION AND REPRESENTATION}

The aim of this essay is to analyse tensions between repetition and representation of death and violence in four cases of contemporary theatre, drama, and novel, representing the European landscape of contemporary theatre and fiction. The first case is the theatre director Oliver Frljić ${ }^{1}$ and his performances Damned Be the Traitor of His Homeland! (2010) and Our Violence and Your Violence (2016). According to him, the inflation of death and the incessant repetition of the unrepeatable emphasise a theatrical mechanism that always remains a representation of a certain external reality. The second and third cases deal with two (no longer) dramatic writers: ${ }^{2}$ Anja Hilling ${ }^{3}$ and Simona Semenič, ${ }^{4}$ two outstanding representatives of German and Slovene (no longer) dramatic theatre and drama, who explore verbal repetitions in their texts (for example, the former in Schwarzes Tier Traurigkeit (2009); Monsun (2005); and the latter in the feast or the story of a savoury corpse or how roman abramovich, the personage janša, julia kristeva, age 24, simona semenič and the initials z.i. found themselves in a puff of tobacco smoke (2010) and thus produce tensions between repetition and representation in which the first mechanism undermines and challenges the second and produces a specific poetic or aesthetic device-an 
effect of ostranenie or defamiliarisation (Shklovsky) or différance (Derrida). ${ }^{5}$ The fourth case are novels by famous German writer Winfried Georg Sebald, ${ }^{6}$ largely concerned with themes of memory, loss of memory, identity (both personal and collective), and decay (of civilisations, traditions, or physical objects). His works can be interpreted as wanderings between signs, punctuated by black and white photographs-Nicolas Bourriaud defines them as emblematic of a mutation in our perception of space and time, in which history and geography cross-fertilise, tracing out paths and weaving networks. ${ }^{7}$

My assumption is that the performances of Frljic and the texts of Sebald, Hilling, and Semenič challenge the theatrical and fictional representation of death as well as the idea of representation itself through compulsive attempts to stage and describe individual and collective death. By using a technique of repetition of death occurring onstage as well as verbal repetition, pauses, and silences, language and sound effects such as interjections, the works of the selected contemporary artists reveal a standstill of theatrical and fictional mechanisms.

It is these mechanisms, producing fiction and most often remaining hidden, that oust any framework in terms of content and theme, thus remaining the only ones visible. The procedures of their dramatic text, fiction, and theatre therefore embody Bakhtin's dialogicality $^{8}$ and polyphony as well as Julia Kristeva's intertextuality ${ }^{9}$ and the Deleuzian difference and repetition. ${ }^{10}$ By using their own personal, wartime, and political traumas, they keep asking universal questions about the boundaries of artistic and social freedom, individual and collective responsibility, tolerance and stereotypes, and thus create a specific artistic critique of today's society.

\section{TOUCHING SOCIETY'S RAW NERVES}

Let us begin with Oliver Frljić. During the last ten years, he has made a habit of touching society's raw nerves. His 2008 version of Euripides' Bacchae, produced for the Split Summer festival in Croatia, contained uncomfortable parallels with crimes committed during the Homeland War of 1991-95 and was abruptly removed from the repertoire by the Croatian National Theatre in Split. Probably the biggest international success came with Frljićs production Damned Be the Traitor of His Homeland! (2010), ${ }^{11}$ a devised theatre performance conceived with the actors of the Mladinsko Theatre in Slovenia.

Since then, Frljić has barely stopped to catch his breath: success has turned him into the most talkedabout director in the ex-Yugoslav region. His abrasive, socially critical performance on the verge of documentary theatre, Zoran Đinđić (dealing with the assassination of Serbian prime-minister Đinđić in 2003), performed in Belgrade's Atelje 212 in 2012, provoked both mass walk-outs and standing ovations. With this performance, Frljić became a director exposing (the lack of) collective ethics and has remained till present times a central figure of the post-Yugoslav theatrical landscape. His two-year leadership of the National Theatre in Rijeka provoked many scandals, political attacks, and even death threats and led to his resignation. His Trilogy on Croatian Fascism (2014-2015), presenting the WWII collaboration of theatrical artists with the pro-Nazi government, provoked public protests of the War Veterans Movement. That police had to be called upon to protect his theatre performances, indicates the strongest reactions of some political groups to his political theatre.

One could say Frljić uses theatre to create a public forum for open debate in order to shape theatre as a specific producer of truth in the sense of Alain Badiou defining the relation between art and truth in his Handbook of Inaesthetics:

By 'inaesthetics' I understand a relation of philosophy to art that, maintaining that art is itself a producer of truths, makes no claim to turn art into an object for philosophy. Against aesthetic speculation, 'inaesthetics' describes the strictly intraphilosophical effects produced by the independent existence of some works of art. ${ }^{12}$

According to Badiou, the relation of philosophy and art is very different from that claimed by classical aesthetic concepts: philosophy and art do not 
communicate directly but through a relation to a third term, which they do not reach in the same way-truth. If philosophy does not produce truths of its own, it nevertheless has something to say about truth. Art produces truths of its own, but it does so by dealing with sensible images, objects, bodies, or the material dimension of artistic language. This produces the following paradox: along with mathematics, politics, and love, art is considered to be one of the "conditions" of philosophy. Frljić therefore shares with Badiou the concept of the thought of art as something that is not extrinsic-it is art itself.

Frljić deliberately wants to say something about society in his performances, using provocation with repetitions as a generative strategy. He deliberately and repeatedly provokes actors to generate material from their own lives and reactions during the process; and the actors provoke the audience to generate responses and involvement during each performance. Frljić is aware that philosophy does not produce truths of its own but, nevertheless, has something to say about truth-it seems much more important for him to use art as a specific procedure to produce and distribute truth about today's society. For both Badiou and Frljić, truth does not occur in the context of knowledge at all, which is relegated to "opinion". They see knowledge as ultimately fragile, subject to change.

\section{TOWARDS THE AESTHETICS OF RESISTANCE}

Frljićs 2016 international co-production Our Violence and Your Violence premiered at Wiener Festwochen, dealing with the very fervent theme of migration and European identity. In a time when refugees have become a "flood" in biblical, nearapocalyptic terms, Frljić mixed political incorrectness with drastic physical theatre scenes that were meant to shock. The performance was full of overtly political references (including religious symbols and references to rape, torture, terror, fascism, and Islamophobia) in an almost old-fashioned sense of the political theatre of the 1960s and 1970s. Commissioned by Berlin's HAU Hebbel am Ufer as a critical homage to Peter Weiss's novel on radical resistance Die Ästhetik des Widerstands (The Aesthetics of Resistance, 1975-1981), the performance was full of what critics named "relentless stereotypical violence" in which "one cannot but sense Frljić's overcompensating furor, trying to 'explain' Islamic terror in the wake of a long history of Western colonial and religious terror, fascism and capitalist exploitation." ${ }^{13}$

The actors and the director delighted in attacking the hand that also fed them, namely the European theatre festivals and left-wing producers. The production flooded the stage with refugees and prisoners, who, at one point, performed a hallucinatory trance dance in orange Guantánamo detainee uniforms, and, the next moment, appeared naked with calligraphic Arabic inscriptions on their skin, as if they had walked out of a Shirin Neshat video. Later in the play, Jesus descends from the cross to rape hijab-wearing Muslim women; the dancing Guantánamo prisoners sit in a circle and torture a newly arrived "Syrian" refugee, while an announcement request the audience to observe a minute of silence for the victims of terrorist attacks in Paris and Brussels. This is followed by a Handke-like attack against the audience: "I am most ashamed for you, the theatre audience. For you, death is an aesthetic event." As Johannes Birringer sums it up in Critical Stages:

Frljićs heavy metal theatre using blatant, fetishized violence on stage can be called plakativ (in German), that is, trotting out shrill political signs, shoving them into our faces, and casually intermixing them with the archive of performance gestures that once resonated (for example, mimicking Carolee Schneemann's iconic Interior Scroll, a hijab wearing actress /.../ pulls an Austrian flag from her vagina). /.../ The propulsive in-yer-face theatre tends to privilege the political content through spectacular gestures that heighten the theatrical affect. It is the loudness of the affecting that turns me off. I wonder whether current dance theatre productions pursuing a more abstract spiritual technique of ritual, more subtle tonalities, are able to dig deeper, make us listen differently. ${ }^{14}$ 
Frljić has described his approach to collaborative work and theatrical materials as follows:

I invite the actors to deconstruct my power as a director in the process. In the beginning, I don't address this issue directly. Instead, I am trying to create the situation where they can start to think, how the distribution of power in theatre is not something normal, although we treat it as such. These situations are set to create performative answers to theatrical normalisation of power divisions. Sometimes I start from the text and I use it to demonstrate how Derridian theological stage operates. When this is clear, we go to higher levels and other questions. How can we make our work efficient outside the theatrical realm of symbolic exchange? How can we start to produce real effects in broader social contexts? The basic question is the question of performativity. In the words of Jon McKenzie, perform or else. ${ }^{15}$

He alluded here to two crucial thoughts about the status of the contemporary performing arts. The first is a reference to Jacques Derrida's famous essay on Artaud, Le théâtre de la cruauté et la clôture de la representation, with his concept of theological space, borrowing the concept from Artaud. He describes the theological stage as enabled by an Author-Creator who, absent and from afar, regulates the time or the meaning of representation. In his performances, Frljić has tried to deconstruct this theological stage in which the performance artists are but "interpretive slaves" on Earth, carrying out the univocal will of the Author-Creator (the director as an invention of the twentieth century not excluded). The second refers to Jon McKenzie's book Perform or Else, asserting that there is a relationship of cultural, organisational, and technological performance, and demonstrating that all three paradigms operate together to create powerful and contradictory pressures to "perform ... or else". McKenzie's intervention in contemporary critical thinking profoundly shapes Frljićs understanding of 21st century structures of power and knowledge. Frljić could also have been alluding to Deleuze's Différence et Répétition:
"Theatre is real movement, and it extracts real movement from all the arts it employs. This is what we are told: this movement, the essence and the interiority of movement, is not opposition, not mediation, but repetition."16

In his work for stage, Frljić asks himself universal questions: about the boundaries of artistic and social freedom, individual and collective responsibility, tolerance and stereotypes.

What he has in mind is Deleuzian theatrical space, a "theatrical space, the emptiness of that space, and the manner in which it is filled and determined by the signs and masks through which the actor plays a role which plays other roles; we think of how repetition is woven from one distinctive point to another, including the differences within itself." ${ }^{\prime 7}$ Both Deleuze and Frljić are searching for a way of thinking about difference that does not view it as a meaningless chaos or as the negation of identities or of things we can represent. Frljić theatrically exposes Deleuze's claim that pure difference simply happens to us and is not the result of direct actions. Repetition is a process that underlies all identities. If difference is to make any sense, it must be a difference between two things, two ideologies, two realities.

Frljić shows this difference between things by using an example of a peripheral sphere of European theatrical, cultural, and political semiosphere-the breakup of Yugoslavia in the 1990s, followed by a severe war in Croatia and Bosnia, leading to genocide in Srebrenica. The title of one of his most influential performances, Damned Be the Traitor of His Homeland!, comes from the last verse of the national anthem of the now defunct country. It starts with a scene as if taken out of Emir Kusturica’s Golden Palm-winning film Underground (1995): the stage floor is strewn with dead bodies with brass-band musical instruments in their hands. Shortly afterwards, the air in the instruments starts moving and it's not long before we understand that it's not just wind blowing through them. The sounds get stronger and stronger, they intertwine into a melody and, with the soaring music, the dead, too, rise up. Throughout the performance, these same people are repeatedly killed and rise up again and again. Frljić reasons: 
In the end, we're always counting corpses. And these corpses become the stakes in new political projects. Certain bodies can be remembered and buried with all the honours. Other corpses turn us into Antigones. We must speak about the value of each human life, because if we don't, our thousand would be nothing compared to their ten thousand. But this is a score that we consider unfavourable. We have, after all, died a little less and slaughtered a little more. Whose side are you on: Eteocles's or Polyneices's? ${ }^{18}$

With its compulsive attempts to repeatedly stage collective death, this performance challenges theatrical representation of death as well as the idea of theatre representation itself. The repetitions of death that appear onstage in almost regular intervals and after which the protagonists "come back to life" expose the standstill of theatre mechanisms of representation.

\section{THE SCHIZOPHRENIC DISMEMBERMENT OF BODY AND VOICE}

Danijela Kapusta notes that for Anja Hilling and her contemporaries the text is not "a firmly set 'Nonplusultra' but 'a material as a beginning of something yet to come."' 19 Nevertheless, Hilling is strongly against the cold and distanced approach and tries to find a way to transform the postdramatical playfulness of signifiers into something that has emotion and feeling. The playwright sees Black Beast Sorrow as her "most bombastic text" in which she "tried to test the catastrophe in relation to the nothingness of human life." ${ }^{20}$ She left behind the "pure" interiority which she shared with British playwrights and moved closer to a dissolution of the boundary between exteriority and interiority. In Black Beast Sorrow, a forest fire serves as a catalyst of the theatrical action: the social construct of the individual is overcome. Individuality is shed to reach a higher level of reflection, free of personal desires:

Perhaps that's it. You plough on, because you're thirsty. This feeling is possibly stronger than the pain. Perhaps you know, that when you won't feel thirst anymore, pain will no longer be an issue. But you've not yet reached that stage on this little excursion, the place, where nothing exists anymore, no wishes, only the relief from pain. ${ }^{21}$

Hilling's play Monsun narrates the impact of the death of a child upon two couples, stressing inability to communicate and schizophrenic dismemberment of body and voice. Influenced by two masters of absurd drama, Pinter and Beckett, Hilling uses Brechtian techniques (V-effekt) as well as defamiliarisation (Shklovsky) in order to highlight the absurd repetitions of a highly mediatised society. Let us quote an example:

\section{VOICE OF THE RADIO NEWSCASTER.}

What a rain. In Berlin and in Brandenburg. Munich, Hamburg, the whole of Germany is under rain. Also Vienna reports showers. Rain rain rain. I want to go barefoot on the street. Right now. Rain in Prague. Thunderstorm in Moscow. Drops form on the eyelashes. Floodwaves put Scotland under water. In Vietnam many people have lost their homes. What a rain. I feel myself as a wild poppy that tears open its red mouth in the middle of the field. This is how I feel: born again. ${ }^{22}$

Hilling's concern is with contemporary society and, more specifically, German society. The characters do not want to face traumatic past events. That can be interpreted as the basic reason of their incapability to organise their lives towards a successful future. As Birgit Haas points out, the action in Hilling's plays is "realistic, but, at the same time, it is almost too realistic." ${ }^{23}$ This defamiliarised realism can be seen as a hidden criticism of the clichéd aesthetics of television. Hilling does not use deconstructivist devices like Frljić or Semenič in order to break free from the linear and synthetic structure of narration. Nevertheless, she uses the critique of both dramatic and mediatised soap opera form in the Brechtian sense to expose the very repetitiveness of everyday mediatised society. She is pointing to what Haas defines as a specific "transposition-effect": "Whilst Brecht sought 
to achieve a productive 'dialogue' between various layers of history by juxtaposing them, Hilling achieves a productive mutual 'questioning' of the aesthetic realms of television and theatre." 24

In her no longer dramatic procedures, ${ }^{25}$ Simona Semenič goes radically against representation while using repetition and différance. She produces forms one could define as a no longer dramatic text rhizome which has replaced the traditionally understood physicality of the book, the livre-racine (Deleuze, Guattari). ${ }^{26}$ Her texts remind us of William Burroughs and his cut-up method, interpreted by Deleuze and Guattari in A Thousand Plateaus as "the folding of one text onto another, which constitutes multiple and even adventitious roots (like a cutting)" ${ }^{27}$ In her (no longer) dramatic theatre texts, Semenič produces the effect that Deleuze and Guattari define as "a rhizome or multiplicity <...> [that] never allows itself to be overcoded, never has available a supplementary dimension over and above its number of lines, that is, over and above the multiplicity of numbers attached to those lines." 28 Thus, Semenič touches the ideology of nomadic reproduction and distribution elaborated by Deleuze in Difference and Repetition ${ }^{29}$ and returns to his ideas of crowned anarchy. Semeničs plays are therefore "neither imitation nor resemblance, only an exploding of two heterogeneous series on the line of flight composed by a common rhizome that can no longer be attributed to or subjugated by anything signifying." 30

The dialogical form of Semenič's writing has ended up in the company of heterogeneous textual strategies: from stage directions to descriptions that are closer to the novel and prose, to the narrative, essayistic, theoretical, and other techniques, reminding the audience that what they are reading or watching is no longer a realistic dialogue. Let us quote from the very beginning of the already mentioned piece by Semenič with the very very long title the feast or the story of a savoury corpse or how roman abramovič, the personage janša, julia kristeva, age 24, simona semenic and the initials z.i. found themselves in a puff of tobacco smoke:
Simona Semenič:

yes, of course we are in a theatre, but this theatre is about to throw you a very special feast a feast to which some eminent guests have been invited, we shall sit them behind a table (this of course does not mean that there has to be a real table on stage, there can be, of course, there can be a whole line of tables or a pile of them, the entire stage can be a table, the tables can hang from the ceiling upside down or the other way around, there can also be a sign saying table in one or another language, and there can be no sign anywhere and no thing anywhere; no table, no chair and no soup tureen with delicious smelling stew, what I mean to say is, the important thing is that you, the distinguished viewer, can imagine our eminent guests on stage before you having a feast)

this feast is an extremely special and significant one

namely, our eminent guests before you on stage, respected publikum, are feasting on a corpse

so, yes, dear viewership

each spoonful of the stew that the eminent guest puts in his mouth is a spoonful of a stew cooked from a dead body therefore, this corpse that you see on stage, this corpse is not a living personage (dramatis persona, if I had it my way) this corpse was once a living personage, once, before it ended up in the stew I am about to serve at tonight's feast

this personage

before you, being impersonated

(and I mean impersonated in such a manner that takes your breath away)

by a true theatre star

it is a personage who actually gets cooked in the stew that the guests, present at tonight's special and important feast, which will start any minute now, are about to eat. ${ }^{31}$

As is clear from the quotation, Semenič proposes the structure of what Deleuze would find in Nietzsche's theory and names it "a theatre of unbelief" in which "humour and irony are indispensable 
and fundamental operations of nature" and "the grounding of the repetition in eternal return on both the death of God and the dissolution of the self." ${ }^{\prime 2}$ Thus Semenič leads us to Deleuze's reading of Nietzsche's eternal return as well as his thoughts on univocity and difference. At the same time, she does not duplicate the unstructured workings of the real world but creates instead an aesthetic commentary, dealing with the issue of narrative development, establishing a relationship with the past, and producing a critical narrative of the present.

\section{THE EFFECT OF REALITY AND SENSELESS CRUELTY}

Winfried Georg Sebald characteristically shapes the genre of his writing using a synthesis of a breed of minor genres: biography, autobiography, memoir, travelogue. To these minor literary genres, he also adds non-literary forms: the notebook or family album, which he connects to interrupt the reader's automatised reception. At the same time, with a special form of travelling, which is bound to the combination of genres and their literary and non-literary tactics, his literature produces, with the help of recollections of "archetypical" traumatic images of the First and Second World Wars, the flow of significations and representations which builds social reality. In this way, Sebald creates a singular synchronous genre in which he is able to dialogically add to the novel-as the modernist genre par excellenceother genres and create an intertextual, intergenre, and even intermedial cohesive structure.

Characteristic of that structure is the dynamic of uptake and mutual pollination of genres at the level of fabula as well as narrative. Sebald creates a new, often meta-genre which breaks through the limits of the already known, as if he was constructing a larger unfinished, perhaps even impossible to finish, genre hybrid. Yet it remains primarily narrativefiction work, with some kind of melancholy-infused process of Balzac's contemporary epic structure, $\mathrm{La}$ Comédie humaine, which appears as quotational fibre in the last part of Sebald's "novel" Austerlitz.

It seems that Sebald's procedure, which is carefully plotted and structured, is one of the possible answers to the status of contemporary prose, which in her essay The Grieving of the Soul, dedicated to the author's prose, Susan Sontag describes as "an unproductive inadvertence of literary ambitions and simultaneously the ascendancy of the tepid, the glib and the senselessly cruel as creative fictional subjects." ${ }^{33}$ At this he succeeds in his "fictions"and their accompanying visual depiction-in creating an effect of reality and harrowing extremity. ${ }^{34}$ Precisely that violent effect of reality is the point in Sebald's literary procedure that interests us. It is a special procedure with the help of which he achieves that fiction and facts are not in opposition but in a dialogical relationship, which is stressed through several different literary, textual, and visual procedures, and structures Sebald's romanesque "grievings". Frljić also uses similar procedures, only within the medium of theatre.

In Sebald's writing, which mixes the made-up and documentation, we are (just as in, for example, his novel The Rings of Saturn $)^{35}$ witnesses to exchanges and transverses between the past and the present. This creates a heterochronic temporality which enables the writer to examine and connect two central themes to one another: time and memory. For Sebald, memory is as personal as it is historical. We remember only the introductory chapter of The Rings of Saturn, which in a fundamental and nearly unnoticeable arc moves from Suffolk in August 1992 to a hospital in 1993, and to Kafka, the memory of the narrative friends, and history of art in the 17th century. Those shifts among others enable a multimodality of the novel, which, alongside its textual material and iconographic-documentary material of photography, intertwines heterogeneous verbal and non-verbal signs in new combinations. Bourriaud interprets that as an altermodernistic ${ }^{36}$ "valorising of connections, which establish between the text and images as special paths, which artists establish in multicultural landscapes, transitions, which they impose in order to connect the ways of expressing and communication." 37 With his literary and poetological procedures, Sebald generally "shows, how the memory of past people and events in our lives is something that makes us afraid, that shapes the space around us." 38 
The problem which arises, and which I examine together with Mark Richard McCulloh and his book Understanding W. G. Sebald, is: can we truly interpret Sebald as "a writer who draws on his knowledge of several literatures and literary periods to create a new kind of documentary fiction that owes much" to Borges, Kafka, Bernhard, Nabokov, and even Stendhal as well as Eco and Calvino, yet differs from postmodernist prose in that he is not "fictionalizing facts" but "making facts fictive by binding them so deeply into the forms of his narratives that these facts seem never to have belonged to the actual world"? 39

In an interview for Dutch television in 1998, Sebald emphasised his attitude towards the past, the present, and the future, which nicely reveals the ways of his perception and framing the world:

In one sense the future does not interest me or that narrator figure at all because, knowing what I do, I fear that it can only be blighted and that, therefore, the past, horrendous though it is, with all its calamitous episodes, nevertheless seems to be some kind of refuge because at least the pain that you had there is over. It is no longer acute, it has been subdued and so the presence of the past has something very ambivalent about it. On the one hand it is burdensome, heavy, it weighs you down, on the other hand it is something that liberates you from the present constraints. ${ }^{40}$

In his works, Sebald produces a consciousness which is like "a theatre that blends memory, hallucination, deceptive memory, dreams, soliloquy and the stream of immediate perceptions." ${ }^{31} \mathrm{McCulloh}$, in a chapter of his book Blending Facts, Fiction, Allusion, and Recall, produces a metaphor of Sebald's prose as an inner theatre whose owner "is at once actor, audience, and playwright." ${ }^{22}$ That metaphor takes us to Frljić, to his theatre, which likewise creates connections of fictions and facts. Just like Sebald, Frljić also creates une salle des pas perdus, a space of lost steps, in which reside the author with signifiers, of which the signified are by no means lightly sought and found, and the reader, whom the author invites on a journey between the signifiers and signified.
The reader is enticed to a fundamental architecture of Sebald's prose (and Frljićs theatre) in which he will meet with the narrator (or narrators-actors)not that it would enable unambiguous identification or clear distance. The meetings in text and in theatre are no less intense because of it.

Sebald addresses readers who know how to read. Frljić, Semenič, and Hilling also create their works for such readers and spectators. They all play with the readers or the spectators, they play hide-andseek with contemporary civilisation, which recalls themes of history in order to speak about the present and (dependent upon the desires and projections of the reader/spectator) perhaps also the future. They use the principle of repetition which produces the reader's or spectator's co-responsibility for a creative reading of a text or a performance. Both destroy the readers' or spectators' horizon of expectation and play with Iser's implied reader. ${ }^{43}$

\section{THE ARTAUDIAN RITUAL OF REPETITIONS}

The overflow of corpses produced in the works of Frljić, Hilling, Semenič, and Sebald strives to reduce the value of a certain model of representation. If such a devaluation has occurred in the representation of death, what is the value of real death? To figure that out, Frljić would propose us to watch the news on Syria or ask what Srebrenica means to us today. Little, less, nothing?

The characters of the (no longer) dramatic texts of Hilling and Semenič, fiction-faction novels of Sebald, and the actors of Frljić perform an Artaudian ritual of repetitions. By using the technique of repetitions, Frljić, Sebald, Hilling, and Semenič deliberately blur the line between reality and fiction. They produce a specific quality described by Derrida when speaking about Artaud as smashing the hierarchical organisation of representation that constitutes classical theatre in order to coincide with the original force of life: "this new theatrical arrangement sutures all the gaps, all the openings, all the differences. Their origin and active movement-differing, deferral-are enclosed." ${ }^{4}$ Their specific theatre and fiction of cruelty ventures into 
the play of Danger, consumed in a total expenditure without reserve.

The performances of Frljić and the texts of Sebald, Semenič, and Hilling show us, how representation should move beyond the simplistic reality omnipresent in the mediatised society. They also point out that life without representation and repetition is impossible. But they also oppose the postdramatic idea of theatre and postmodern idea of fiction constituted by a surface of signs and reclaim the right to become (together with the emancipated spectators, of course) the co-producers of meaning.

The discussed authors deconstruct and ironise the horizon of expectation as an achievement of civilisation, since it is a metaphor which they most often use as a goal of this expectation, death, its inevitability, and its repetitions. This can be disruptive for readers and spectators who expect either hermeneutic or mimetic certainty, just as it can be a pleasure for the readers and spectators who appreciate, for example, the resistance produced by interpretations of the texts of Franz Kafka or Heiner Müller. Semenič, Hilling, Sebald, and Frljić play with a series of theoretical and civilisation signifiers and new age mythology, for example, the death of the author and the birth of the reader, which they paratactically interpret through irony. They all share an almost "pathologically" sharp feeling for reality, which they introduce within different media and cultural-political contexts, with an ability to create uncertainty and destabilise us.

If, as Thomas Elsaesser notes, what inhabits the fiction of Sebald's novels are "ruins_the ruins of buildings, bodies, lives" and "a symptom of something else, since coincidence and chance are just like ruins: but nevertheless more ruins of time than space, yet still ruins (of context, order, concept and fate)," ${ }^{45}$ Frljić's productions, Semenič's and Hilling's plays are populated by corpses that testify about the acute crisis of ethics in contemporary world. All discussed authors use biography as one of the ways in our culture to show the desire to redeem life, to save it (or judge it). And when Elsaesser points out that "what Sebald is doing in his stories-rescuing lives that would otherwise fall into oblivion, is strongly rooted in the European imagination because of the millions of lives that the Germans destroyed or ended during World War II and the Holocaust".46 Frljić, Semenič, and Hilling situate the Holocaust in the memory of the entire 20th century as well as the new millennium: from the war in former Yugoslavia to the Rwandan genocide, to the entirely fresh refugee and humanitarian crisis in Syria and Europe.

\section{CONCLUSION}

To conclude, the discussed artists reflect a special dialectic of art and the social, within which fluid, uncontrollable subjects constantly change the contours. They follow the dominant principles of Deleuze's philosophy that we should seek the most complete expression of reality possible, but that this requires creation rather than discovery. The discussed artists all share the belief that creative expression must also be destruction. Art has to go beyond what we are and what we can identify through understanding. Reality as presented in their works is not the sum of all we know or even of all we could in principle know. They all believe that more complete views of reality can only be expressed through acts of creative experimentation. They show that they can steer contemporary theatre and literature through the complexities of the discourse and societal reality of neoliberalism, also in the era of terrorism.

Each artist within his or her medium creates syncretic genres in which prose and theatre form with other genres an intertextual, intergenre, and intermedial structure. With Sebald, Semenič, and Hilling it is implicitly political, while with Frljić it is explicitly political. With all of them it points to what Elsaesser lucidly discovered with Sebald: "he anticipates the other side of the medal or the dark side of Facebook, Twitter and our obsessive online lives: finally, they present the authentic/real attempts of the 21 st century to rescue itself from the final recognition of our mortality." They all "intuitively touch the 21 st century, while they write about [and direct] in and for the 20th." Thus they introduce "the ultimate Facebook of the undead of its own unhappy century" ${ }^{37}$ 


\section{References}

Badiou, Alain. Handbook of Inaesthetics. Stanford: Stanford University Press, 2005.

Birringer, Johannes. "Atmospheres of Dividual Performance." Critical Stages/Scènes Critiques, The IATC journal/Revue de l'AICT 14 (2016).

Birringer, Johannes. "Really Actually Windy: On Environments, Technologies, and Dividual Performances." Theatre Journal 68 (2016): 633-647.

Blackler, Deane. Reading W. G. Sebald: Adventure and Disobedience. Studies in German Literature, Linguistics, and Culture Series. Rochester: Camden House, 2007.

Bourriaud, Nicolas. "Altermodern." In Altermodern: Tate Triennial. London: Tate Publishing, 2009, 11-23.

Bourriaud, Nicolas. The Radicant. New York: Lucas \& Sternberg, 2009.

Deleuze, Gilles, and Felix Guattari. A Thousand Plateaus Minneapolis: University of Minnesota Press, 1987.

Deleuze, Gilles. Difference and Repetition. New York: Columbia University Press, 1994.

Elsaesser, Thomas. "Kontingentnost in naključnost kot ruševini časa: besedilo, podoba in gibanje $\mathrm{v}$ Saturnovih prstanih W. G. Sebalda.” Primerjalna književnost 37 (2014): 25-37.

Frljić, Oliver, Borut Šeparović, and Tomaž Toporišič. "On theatre corpses." Mladinsko Theatre. en.mladinsko. com/performances/reprises-20152016/damned-bethe-traitor-of-his-homeland/e-library.

Garner, Stanton B. Jr. Bodied Spaces: Phenomenology and Performance in Contemporary Drama. Ithaca, NY: Cornell University Press, 1994.

Gibbons, Alison. “Altermodernist Fiction.” In Routledge Companion to Experimental Literature, eds. J. Bray, A. Gibbons and B. McHale. London: Routledge, 2012. 238-252.

Haas, Birgit. "The Return of the Dramatic Drama in Germany after 1989." In Theatre in the Berlin Republic, ed. Denise Varney. Peter Lang, 2008.

Hilling, Anja. "Bistveno je spoznanje o lastni ničnosti"; Interview with Jaša Drnovšek, Delo, 15 Feb. 2013.

- "Monsun." Theater Heute. (Feb. 2006): 47-57.

- Schwarzes Tier Traurigkeit, Berlin: Felix Bloch Erben, 2007.

Jakiša, Miranda. "The Evidence of Srebrenica: Oliver Frljićs Theater Court in Cowardice." In Post-Yugoslav Constellations: Archive, Memory, and Trauma in Contemporary in Bosnian, Croatian, and Serbian Literature and Culture, ed. Vlad Beronja, Stijn Vervaet. Berlin: De Gruyter, 2016. 83-98.

Juvan, Marko. "Svetovni literarni sistem." Primerjalna književnost, 32, 2, (Dec. 2009): 181-212.

-. "Od političnega gledališča $\mathrm{v}$ jugoslovanskem socializmu do političnega performansa $\mathrm{v}$ globalnem kapitalizmu: primer Slovenskega mladinskega gledališča." Slavistična revija, 62, 4 (Oct. - Dec. 2014): 545-558.

Kapusta, Danijela. Personentransformation: zur Konstruktion und Dekonstruktion der Person im deutschen Theater der Jahrtausendwende. Herbert Utz Verlag, 2011.

Lehmann, Hans-Thies. “Politično v postdramskem.” Prev. Anina Marn. Maska, 17, 3/4 (2002): 6-9.
McCulloh, Mark Richard. Understanding W.G. Sebald. Columbia, South Carolina: University of South Carolina Press, 2003.

Pezdirc-Bartol, Mateja. "Vloga bralca v poglavitnih literarnoteoretičnih smereh 20. Stoletja." Jezik in slovstvo, 45, 5 and 6 (2000): 195-206 and 243-252.

Robertson, Roland. "Glocalization: Time - Space and Homogeneity - Heterogeneity." In Global Modernities, ed. M. Featherstone et. al. London: Sage Publications, 1995. 25-44.

Sebald, Winfried Georg. 2001. Izseljeni. [trans. Štefan Vevar]. Beletrina. Ljubljana: Študentska založba.

- "Introduction and Transcript of an interview given by Max Sebald." In W. G. Sebald: History - Memory Trauma. ed. Scott Denham, Mark McCulloh. Berlin: De Gruyter, 2006.

Semenič, Simona. The Feast. 2010. Reprinted on: https://docs.google.com/document/d/1_ S X H O p x W Q L I e p j f v Y i E p i _ P E 96 m ObQMKuYNBE3jvwA/edit

Sontag, Susan. 2000. "Mourning sickness." Published in the TLS of February 25, 2000. Reprinted on: https://www.the-tls.co.uk/articles/public/mourningsickness/

Toporišič, Tomaž. 2016. "Five Questions for Oliver Frljić / Pet vprašanj za Oliverja Frljića = Pet pitanja za Olivera Frljića." Gledališki list Slovenskega mladinskega gledališča in Hrvaškega narodnega gledališča Ivana pl. Zajca Reka - sezona 2016/2017 (1): 4-6.

\section{Notes}

1 Oliver Frljić: Born in the Bosnian town of Travnik in 1976, a refugee during the war in former Yugoslavia. He finished his studies of philosophy, religion, and theatre directing in Croatia where he lives most of the time and works as a director, writer, actor, and theorist. Frljić soon became one of the most daring and influential directors of the region and has been invited to many international festivals and received numerous awards for his staging.

2 We are using the term introduced by a German theatre scholar Gerda Poschmann in her book Der nicht mehr dramatische Theatertext. Aktuelle Bühnenstücke und ihre dramaturgische Analyse [Plays without Drama. Analysing contemporary stage-plays and their dramaturgy] (De Gruyter, 1997). The book introduces the term "no longer dramatic text" in order to discuss how the traditional concept of drama has grown too restrictive and is in obvious need of revision. As contemporary plays in German show, theatre texts make very different uses of the drama form and in some cases depart from it altogether. With this in mind, the study sets out to analyse the dramaturgic concept behind such plays.

3 Anja Hilling: born in 1975, has a degree in theatre studies and German literature. She studied creative writing for stage at the University of the Arts, Berlin. At the 2003 Berlin Theatertreffen, she was awarded the Dresdner Bank Young Dramatists' Prize. In 2007, her plays Sinn and Schwarzes Tier Traurigkeit premiered with big success in Germany and other European countries.

4 Simona Semenič: Born in 1975, studied dramaturgy in Ljubljana. She has won several national awards for her no longer dramatic plays, which have been widely translated, 
presented, and published in Europe and the USA. She has also been involved in several productions as a performer, co-author, director, dramaturg. These shows have toured around Europe, South America, and the USA.

5 We are referring to Lawrence Crawford and his essay, "Victor Shklovskij: Différance in Defamiliarization." Comparative Literature 36 (1984): 209-219; in which he states that Shklovsky's defamiliarisation is one of the many sources of Jacques Derrida's concept of différance: "What Shklovskij wants to show is that the operation of defamiliarization and its consequent perception in the literary system is like the winding of a watch (the introduction of energy into a physical system): both "originate" difference, change, value, motion, presence. Considered against the general and functional background of Derridian différance, what Shklovskij calls "perception" can be considered a matrix for production of difference." (Crawford, 212).

6 Winfried Georg Sebald, born in 1944, Germany, died in 2001, England, was a German-English novelist and scholar. His works are largely concerned with the themes of memory, loss of memory, and identity. They are attempts to reconcile himself with the trauma of the Second World War and its effect on the German people. At the time of his death he was regarded by many literary critics as one of the greatest living authors, and was tipped as a possible future recipient of the Nobel Prize in Literature. His novels include Scwindel, Gefühle (1990; Vertigo), Die Ausgewanderten (1992; The Emigrants), Die Ringe des Saturn (1995; The Rings of Saturn), Logis in einem Landhaus: über Gottfried Keller, Johann Peter Hebel, Robert Walser und andere (1998; A Place in the Country: On Gottfried Keller, Johann Peter Hebel, Robert Walser, and Others), and Austerlitz (2001).

7 In his Altermodern Manifesto Nicholas Bourriaud writes: "Sebald's writings appear to me as emblematic of a mutation in our perception of space and time, in which history and geography operate a cross-fertilization, tracing out paths and weaving networks." Thus his work is creating an experience of speed for the reader while managing to "hold still". The energy of the work is continually renewing itself. It occupies a place of ruminative study and inexhaustible shifting at the same time. See: Bourriaud, Nicolas. "Altermodern". In Altermodern: Tate Triennial. (London: Tate Publishing, 2009), 11-23.

8 See: M. M. Bakhtin, "Forms of time and of the chronotope in the novel: notes toward a historical poetics." In M. Holquist (Ed.), The dialogic imagination: Four essays by M. M. Bakhtin. (Austin: University of Texas Press. C. Emerson and M. Holquist, trans., 1981), 84-258. 9 See: Julia Kristeva, Desire in Language: A Semiotic Approach to Literature and Art. Ed. Leon S. Roudiez, Transl. Thomas Gora, Alice Jardine and Leon S. Roudiez (Columbia University Press, New York, 1990). Julia Kristeva, Revolution in Poetic Language. Trans. Margaret Waller, Intr. Leon S. Roudiez (Columbia UP, New York. 1984).

10 In his highly influential book Différence et répétition (Difference and Repetition), Deleuze tries to develop a metaphysics adequate to contemporary mathematics and science, metaphysics in which the concept of multiplicity replaces that of substance, event replaces essence, and virtuality replaces possibility.

11 Damned Be the Traitor of His Homeland! (Preklet naj bo izdajalec svoje domovine!), director Oliver Frljić; dramaturgs Borut Šeparovič, Tomaž Toporišič; music selector Oliver Frljić; asistant director and choreographer Matjaž Farič; sound designer Silvo Zupančič, lighting designers Oliver Frljić, Tomaž Štrucl. Cast: Primož Bezjak, Olga Grad, Uroš Kaurin, Boris Kos, Uroš Maček, Draga Potočnjak, Matej Recer, Romana Šalehar, Dario Varga, Matija Vastl. Produced by Mladinsko Theatre, Ljubljana, March 3, 2010.

12 Alain Badiou, Handbook of Inaesthetics (Stanford, 2005), 1.

13 Johannes Birringer, "Really Actually Windy: On Environments, Technologies, and Dividual Performances," Theatre Journal 68 (2016): 633.

14 Johannes Birringer, "Atmospheres of Dividual Performance." Critical Stages/Scènes Critiques, The IATC journal/Revue de l'AICT - December/Décembre 2016: Issue No. 14.

15 Pawel Soszynski, "Divine Kraków, Un-Divine Comedy", talk with Oliver Frljić, Theatre/Biweekly. 24. 12/2013. http://www.biweekly.pl/article/4901-divine-krakow-undivine-comedy.html.

16 Gilles Deleuze, Difference and Repetition, translated by Paul Patton (Columbia University Press, New York, 1994), 10.

17 Ibid.

18 Oliver Frljić, Borut Šeparović, Tomaž Toporišič, On theatre corpses. http://en.mladinsko.com/performances/ reprises-20152016/damned-be-the-traitor-of-hishomeland/e-library/

19 Danijela Kapusta, Personentransformation: zur Konstruktion und Dekonstruktion der Person im deutschen Theater der Jahrtausendwende (Herbert Utz Verlag, 2011), 64.

20 Anja Hilling, "Bistveno je spoznanje o lastni ničnosti" / "It is essential to know about your own nullity"; Interview with Jaša Drnovšek (Delo, 15 Feb. 2013).

21 Translation Philip Thorne. German original reads as follows: "Vielleicht ist es das. Du gehst weiter, weil du Durst hast. Vielleicht ist das Gefühl noch stärker als der Schmerz. Vielleicht weißt du, wenn du keinen Durst mehr spüren kannst, spielen auch Schmerzen keine Rolle mehr. Aber wahrscheinlich bist du einfach noch nicht dort angelangt auf deiner kleinen Reise, dort wo es nichts mehr gibt, keinen Wunsch, nur die Befreiung vom Schmerz."

22 Anja Hilling, “Monsun." Theater Heute. Feb. 2006: $47-57,56$.

23 Birgit Haas, "The Return of the Dramatic Drama in Germany after 1989" in: Denise Varney (ed.) Theatre in the Berlin Republic (Peter Lang: 2008), 98.

24 Ibid.

25 We refer to Simona Semeničs postdramatic usage of the inovative textual strategies that subvert the traditional reading conventions and involves the reader more closely into the decoding of the text and its interpretation. Even though she violates dramatic conventions, she at the same time relativises and revitalises them, and her new textual strategies are closely tied to the problems of reception and the power of the theatre today.

26 In A Thousand Plateaus, Deleuze and Guattari launched the concept of rhizome as a critical alternative to the 'root-book'. See: Gilles Deleuze and Félix Guattari, A Thousand Plateaus: Capitalism and Schizophrenia, trans. Brian Massumi (Minneapolis: University of Minnesota Press, 1987). 
27 Deleuze, Guattari, A Thousand Plateaus, 6.

28 Ibid., 9.

29 Gilles Deleuze, Difference and Repetition, translated by Paul Patton (Columbia University Press, New York, 1994), 356.

30 Deleuze, Guattari, A Thousand Plateaus, 10.

31 Simona Semenič, The Feast. 2010: https://docs. google.com/document/d/1_SXHOpxWQLIepjfvYiEpi_ PE96m-ObQMKuYNBE3jvwA/edit

32 Gilles Deleuze, Difference and Repetition, 11.

33 Susan Sontag, "Mourning sickness," published in the TLS of February 25, 2000. Reprinted on https://www.thetls.co.uk/articles/public/mourning-sickness/

34 Ibid.

35 Die Ringe des Saturn (The Rings of Saturn) was written in 1995 and translated into English in 1998. See: W.G Sebald, Die Ringe des Saturn: Eine englische Wallfahrt (Frankfurt am Main: Eichborn Verlag, 1995). W. G. Sebald, The Rings of Saturn (London: New Directions Books, 1998).

36 On the basis of Bourriaud's theory, Alison Gibbons in the book Routledge Companion to Experimental Literature dedicates a special chapter to altermodernistic prose, which characterises a particular attitude towards form, time, and identity. The object of Sebald's prose, alongside the authors of the 21st century (Liam Gillick, Brian Castro, Charles Avery).

37 Nicolas Bourriaud, The Radicant (New York: Lucas \& Sternberg, 2009), 44.

38 Ibid., 45
39 Mark Richard McCulloh, Understanding W. G. Sebald (Columbia, South Carolina: University of South Carolina Press. 2003), 25.

40 Winfried Georg Sebald, "Introduction and Transcript of an interview given by Max Sebald" in W. G. Sebald, History - Memory - Trauma, ed. Scott Denham, Mark McCulloh. (Berlin: De Gruyter. 2006), 23-24.

41 McCulloh, Understanding W. G. Sebald, 25.

42 Ibid.

43 Here we have in mind the quality that Mateja Pezdirc Bartol put forth in regard to Wolfgang Iser in the article "The Role of the Reader in the Principle Literary Theory Directions of the 20th Century", where she notes the special interaction between the work and the reader, which is interesting also in the process of reading Sebald's prose as in the process of watching Frljićs productions: "The expression marks active participation of the reader in the reading process, but the expression belongs neither to the text nor to the reader, but to both, since it includes the prestructure of the text and the reader's actualisation of the possible meaning." See: Pezdirc-Bartol, "Vloga bralca v poglavitnih literarnoteoretičnih smereh 20. stoletja." Jezik in slovstvo, 45/6: 195-206, 243-252, 252.

44 Jacques Derrida, Writing and Difference, tr. Alan Bass (Chicago: University of Chicago Press, 1978), 242.

45 Thomas Elsaesser, "Contingency and coincidence as the ruins of time: text, image and motion in W. G. Sebald's The Rings of Saturn" (Primerjalna književnost 37, 2, 2014: 25-37), 30.

46 Ibid., 31.

47 Ibid., 35.

\section{Tomaž TOPORIŠIČ}

Teatro, radijo, kino ir televizijos akademija, Liublianos universitetas, Liubliana, Slovėnija

\section{MIRTIS IR ŽIAURUMAS ŠIUOLAIKINIAME TEATRE, DRAMOJE IR ROMANE (OLIVER FRLJIĆ, ANJA HILLING, SIMONA SEMENIČ IR GEORG WINFRIED SEBALD)}

Santrauka

Siekdami ištirti, kaip literatūra ir menas veikia signifikacijų ir reprezentacijų cirkuliacijoje konstruojant socialinę realybę, koncentruosimès ị specifinius bruožus, vienijančius ir siejančius keturių šiuolaikinių Europos autorių darbus: mirties ir žiaurumo infliacijos ar „lavonų pertekliaus“ tematika autorių romanuose, dramose, performansuose. Bosnijos ir Kroatijos režisieriaus Oliverio Frljićo trikdantys, šokiruojantys spektakliai, kuriuose autorius pasitelkia savo asmenines, karo laikų ir politines traumas ir taip iškelia universalius klausimus apie meno ir socialinès laisvès ribas, individualią ir kolektyvinę atsakomybę, toleranciją, stereotipus.

Dviejų (jau nebe) dramaturgių dramos: Anja Hilling ir Simona Semenič - dvi išskirtinès Vokietijos ir Slovènijos (jau nebe) dramos teatro ir dramos atstovès, savo tekstuose tyrinejjančios specifinę įtampą tarp pakartojimo ir reprezentacijos, kuriuose pirmasis mechanizmas meta iššūkius ir nustelbia antrąji, taip formuodamas savitą poetiškumo ir estetiškumo aparatą, produkuojantị ostranenie / defamiliarizacijos (Shklovsky) ar différance (Derrida) koncepcijų poveiki. Taip pat Winfriedo Georgo Sebaldo romanai, kuriuose autorius klaidžioja tarp ženklų labirinto, 
akcentuojamo monochrominių fotografijų, kurias Nicolas Bourriaud apibūdina kaip kaitos išskirtinumo ženklus mūsų erdvès ir laiko suvokime, kur istorija ir geografija valdo rūšies pliuralumą ir ịvairiapusiškumą, rūpestingai nutiesdamos takus ir ausdamos interakcijų tinklus.

Tekste analizuosime ne tik subjektų pozicijų konfrontaciją, bet ir koncentruosimès ties „meno“ ir „visuomenès“ dialektika, kurioje fluidiški, nevientisi subjektai nuolat ardo ribas. Permąstant kritinę nuostatą, kad šiuolaikinis menas pirmiausia domisi realybe, straipsnyje taip pat aptariama, kaip šiųdienis teatras ir fikcija atlieka sudètingo diskurso, neoliberalios realybès funkciją terorizmo amžiuje. Tekste pabrèžiamas minètiems autoriams būdingas bendras įsitikinimas, jog destrukcija taip pat yra kūrybine išraiška.

Galiausiai tekste išlaikysime leitmotyvinę mintị, kad menas turi būti daugiau nei esame mes bei tai, ką galime atpažinti supratimo procesu. Taigi pabrěžiama, kad menas kvestionuoja, moduliuoja ir dalyvauja istorijų, idiomų, kontroversijų, liudijimų cirkuliacijoje, jis taip pat išviešina dezinformaciją globalaus netikrumo akivaizdoje.

Reikšminiai žodžiai: Winfried Georg Sebald, Oliver Frljić, Simona Semenič, Anja Hilling, šiuolaikinis teatras, skirtumas ir pakartojimas, teatro ir fikcijos politika, Europos teatras, altermodernizmas, bendruomeninis teatras.

\section{Tomaž TOPORIŠIČ}

Assoc. Prof. Phd Tomaž Toporišǐč

Dean for Study Affairs

Department of Dramaturgy and Performing Arts

Academy of Theatre, Radio, Film and Television, University of Ljubljana, Slovenia

$$
\text { UL AGRFT }
$$

Nazorjeva 3, SI-1000 Ljubljana, Slovenia

tomaz.toporisic@agrft.uni-lj.si 